\title{
The World Trade Organization and the Promotion of Effective Dispute Resolution: In Times of a Trade War
}

\author{
Asif H. Qureshi*
}

\begin{abstract}
This chapter focuses on dispute settlement in the field of international trade within the World Trade Organization (พто) along with the contribution of the wTo to the resolution of foreign trade disputes in domestic systems. This discourse is set under the shadow of the current impasse in the WTO, precipitated by the United States' blocking of appointments of Members of the Appellate Body of the wTo. In particular the chapter sheds light on the reasons for the US decision to block future appointments and possible legal analysis of the US actions. In this discourse the notion of a 'trade war' is explored along with the capacity of the wTo to manage a trade war. The chapter concludes with the suggestion for a holistic approach to manage the current and future such crisis-with particular reference to the interface of the national security defence, both within the domestic and international legal regimes, with dispute settlement processes. This chapter does not purport to be exhaustive of the issues raised.
\end{abstract}

\section{$1 \quad$ Introduction}

There is much in the name of national security that can and has enabled politicians to galvanise public opinion in support of actions leading to trade wars. In the same vein, the mantra of 'unfair trade', along with efforts to reorganise the world trading order through its initial deconstruction, a la trade wars outside the World Trade Organisation (WTO), whilst crippling its Appellate Body (AB), is a phenomenon that has similar populist characteristics to the national security narrative. Yet there has to be clarity in the concept of national security as much as the notion of 'unfair'. Moreover, both need the rule of international law in their invocation and application. The justification of national security

* Asif H Qureshi, professor of International Economic Law, School of Law, Korea University, Seoul, Korea, and Barrister, Quadrant Chambers, London, UK, Asif@korea.ac.korea.

(C) ASIAN INFRASTRUCTURE INVESTMENT BANK (AIIB), 2019 | DOI:10.1163/9789004407411_011 
for departures from international obligations, and the deconstruction of the existing world trading order in the name of fairness through a trade war, are essentially phenomena that strain the application of the law, the rule of law and established international systems of deliberations.

Against this background, this chapter will focus on the current state of play of the WTO dispute settlement system, ${ }^{1}$ in particular through the apparatus of the $\mathrm{AB}$ (Section 2). The chapter will also highlight the less considered but nevertheless important role the wTo has played in inculcating effective dispute settlement mechanisms, albeit in the trade sphere at the domestic level (Section 3). The chapter will lastly focus on the capacity of the wTo dispute settlement system in managing 'trade wars' (Section 4), before offering brief conclusions (Section 5).

Dispute settlement at the level of the wто has a relationship with dispute settlement at the domestic level. Not only does the wTo law set out a code of conduct in the sphere of international trade to be implemented at the domestic level, it also prescribes a legal machinery at the domestic level for the effective implementation of that code, which if not complied with is the subject of dispute settlement at the wTO level. It is also the subject of review through the WTO Trade Policy Review Mechanisms (TPRM). The effectiveness of the WTO dispute settlement system therefore ensures the efficacy of the domestic dispute settlement process. Moreover, a paralysis of the WTO dispute settlement, involving actions outside the framework of the WTо by governments, usurps foreign trade decisions at the national level to the executive branch from relevant domestic stakeholders, thus undermining the set domestic judicial processes prescribed under the WTO.

As of January 2019, the WTо dispute settlement system is still operationaljust about. Since January 1995 there have been some 600 complaints involving 419 Panel requests; an aggregate of 220 adopted Panel Reports; and 136 adopted AB Reports. ${ }^{2}$ This record level of success had earned the system the title of being the 'crown jewel' of the WTO. Since around June 2017, the system has been

1 For a general overview of the WTo dispute settlement system see Qureshi and Ziegler 2011, 343 .

2 <http://www.worldtradelaw.net/databases/basicfigures.php> accessed ${ }_{15}$ February 2019. One arbitration under art 25 of the Understanding on Rules and Procedures Governing the Settlement of Disputes (Dispute Settlement Understanding) so far. 
under severe stress-indeed has been described as undergoing asphyxiation. This is because of the United States' refusal to allow the filling of vacant positions of judges in the $\mathrm{AB}$ (known in the wTO not as judges but as members of the $\mathrm{AB}$ ). The US has been able to do this because decisions in the Dispute Settlement Body (DSB) of the wTO need to be arrived at by consensus with respect to the appointments of $A B$ members.

The $\mathrm{AB}$ comprises of seven members. Currently however there are only three members left. Out of these three, the tenure of two will expire at the end of December 2019. For a division of the $A B$ to preside over an appeal, three members are needed. ${ }^{3}$ Thus, the $\mathrm{AB}$ is currently operating at less than half its capacity. If the number of presiding $\mathrm{AB}$ members declines further, without being replaced by the end of this year, (as it is likely to do so, given the remaining tenure of two of the remaining $\mathrm{AB}$ members), the $\mathrm{AB}$ will not be able to function. If the $A B$ cannot function then practically the whole dispute system will come to a halt. This is because panel decisions if appealed will not be adopted by the DSB until the appeal process is completed. ${ }^{4}$ Thus, a losing party could just let the case drag on by lodging an appeal and pending that appeal the Panel Decision will have no effect. It is however open to parties to resort to arbitration under Article 25 of the Dispute Settlement Understanding (DSU), which will be binding on the parties. Thus far there has been only one instance of such use of this arbitral facility. ${ }^{5}$

The reasons for the US veto on the appointments of $A B$ members are complex. They have been proffered in dribs and drabs, and involve both procedural and substantive concerns, as follows: ${ }^{6}$

- The fact that members of the $A B$ continue to preside over cases after the expiry of their tenure. Such continuation takes place under Rule 15 of the Working Procedures of the AB. The US contends this is a matter for the DSB and cannot be deliberated upon through the AB Working Procedures. The US view is that Rule 15 not a decision of the DSB. It was simply notified to it by the AB.

- The US senses a particular negative approach taken by the AB in disputes involving anti-dumping measures in the case of dumping $\left(\mathrm{AD}^{7}\right)$, and

3 If US continues to block AB will cease to function in December 2019 when the tenure of the US Member Tom Graham and the Indian Member Ujal Singh Bhatia expire.

4 See wто, Dispute Settlement Understanding, art 16.

5 See $<$ www.worldtradelaw.net $>$ accessed ${ }_{15}$ February 2019.

6 Fabry and Tate, 7 June 2018; Bhatia, 3 May 2018; ICTSD, 28 June 2018; Office of USTR 2018; US Mission to Geneva, 27 August 2018.

7 Agreement on Implementation of Article vi of the General Agreement on Tariffs and Trade 1994. 
countervailing measures to offset subsidies $\left(\mathrm{ASCM}^{8}\right)$. The US has lost a significant number of appeals in such cases. Notable cases involve the AB rulings on the US methodology of calculating dumping popularly known as Zeroing; and the interpretation of the definition of State-Owned enterprises in the context of China under the ASCM. ${ }^{9}$

- Since 2011 the US has expressed concern with respect to the duration of appeals which have taken more than 90 days. Current average has been one year. The longer this period the more likely a Member whose term has expired will continue and create a situation wherein one country has two nationals holding a post in the $\mathrm{AB}$. The US has suggested that all $\mathrm{AB}$ reports adopted after the 90 days deadline should be treated as non-binding. ${ }^{10}$

- Generally, the US perception of AB judicial activism. Overreaching/obiter dicta/de novo reviews/establishment of precedents/dependence on $\mathrm{AB}$ Secretariat and engagement in constructive ambiguities.

In sum, the US concerns are not merely procedural in terms of how the $A B$ is constituted and operates but also substantive in relation to the law that has developed through the $\mathrm{AB}$. In particular, the law as it has been adjudicated with respect to Chinese practices and trade remedies applied to Chinese exports.

In the circumstances, the now protracted US blocking of the recruitment process for $\mathrm{AB}$ judges in the wTо has to be understood in the context of further general reforms in the decision-making processes in the wTO-namely consensus decision making which both allows one member of the wTO to hold to ransom the rest of the members of the wTO and which on the other hand allows for protracted decision making - and not simply in terms of the reform of the $\mathrm{AB}$ specifically. Moreover, there is the need to address the manner in which the substantive law of the Wто accommodates different ideologically organised economies in the application of its disciplines. However, be that as it may, that the US block simply cannot continue is almost universally accepted. At the political level, in this 'member obsessed' wTO, there is much discourse on the resolution of this impasse. However, this political chatter has been woefully ineffective, lacking in force and rigour. Outside the Wто there has also

8 Agreement on Subsidies and Countervailing Measures.

9 WTo, Definitive Anti-Dumping and Countervailing Duties, 11 March 2011. In this case the US objected to the narrow definition of State Owned Enterprises (associated/ vested with governmental authority) based on ILC Draft Articles of State Responsibility and the adoption of the Punta del Este Declaration as the preamble to ASCM, when in the US view, there is in fact no such reference in the ASCM because there was in the negotiations for the ASCM no agreement on the aims and objectives of the ASCM and thus no agreement deliberately on the inclusion of a preamble to the ASCM. 
been much focus including the suggestion for minimising the continued negative consequences of this impasse through some revision of the wTо Appellate Body Working Procedures; majority voting in the Ministerial Conference of the wто; a wто dispute system without the US; agreement amongst the parties not to appeal; and finally, further arbitration as a proxy to the AB. ${ }^{11}$

However, is there here also the need to explore the legal avenues open to bring the US to account for its disruptive use of the consensus decision making process in the $\mathrm{DSB}$ ? First, is the US blocking of the AB member recruitment process in the DSB an 'abuse' of the member's prerogative to participate in the decision-making process in the DSB? Does the consensus decision making in the WTO partake of engagement in it that is arbitrary, capricious, abusive and/or unreasonable? The US has not given specific reasons in terms of the particular decision to appoint or the process involved in appointing a new member within the agreed process of appointment. Second, can there be an assumption that every minutia of decision making has to be the subject of consensus decision making (including, for example, date, timing and the very launching of the recruitment) such that it unravels an already agreed consensus of having an $\mathrm{AB}$ comprising of seven members? Of course, the US could block the appointments of individuals at the time of the decision involving the selection of a particular candidate, on the basis of the suitability of the candidates in question, consecutively in the selection processes as the vacancies arise. This is in the circumstances the only technically appropriate option for a State taking such a strategy but one more disruptive and insidious. Third, consensus decision making in the DSB is set alongside with the automaticity of the adoption of Panel reports qualified by the negative consensus rule with respect to a decision not to adopt a Panel report. Can the paralysis of the $A B$ resulting in the non-adoption of a Panel report be understood as undermining the automaticity of the adoption of a report by the DSB? This raises interesting questions as to the interpretation of Article 16 of the DSU, which reads as follows, in relevant parts:

\section{Article 16}

Adoption of Panel Reports

4. Within 60 days after the date of circulation of a panel report to the Members, the report shall be adopted at a DSB meeting (7) unless a party to the dispute formally notifies the DSB of its decision to appeal or the DSB decides by consensus not to adopt the report. If a party has notified its decision to appeal, the report by the panel shall not be considered for 
adoption by the DSB until after completion of the appeal. This adoption procedure is without prejudice to the right of Members to express their views on a panel report.

There are two points to be made here. Firstly, it does not necessarily follow that the whole dispute settlement system will collapse if there is no longer an AB. A one tier system could still continue. Under Article 16, in the circumstances where the $A B$ is no longer functioning, there are two alternative conditions set which could displace the adoption of a panel report, namely, a party to a dispute may appeal, or the DSB by consensus decides not to adopt the report. The decision to appeal is subject to Article 3 paragraph 7 of the DSU, in particular the first two sentences of paragraph 7 which reads as follows: 'Before bringing a case, a Member shall exercise its judgement as to whether action under these procedures would be fruitful. The aim of the dispute settlement mechanism is to secure a positive solution to a dispute'. In such circumstances, is an appeal, where the $\mathrm{AB}$ is no longer functioning, a fruitful exercise? Granted the party in question needs to make this decision under its judgement, could this edict nevertheless have a bearing in the interpretation of the DSB's adoption of a panel report automatically? Clearly the conditions in paragraph 4 of Article 16 were not intended for a circumstance where the $A B$ is no longer operational. Thus, the DSB must adopt a report in circumstances where the AB is not operational, since the purpose of the first condition, namely, 'unless a party to the dispute formally notifies the DSB of its decision to appeal' is simply to temporarily deny effect to the decision pending an appeal, and not to empower a party to divest the DSB under Article 16 of the automaticity of the adoption of a report, unless there is a negative consensus not to adopt. In such circumstances, the adopted report could have an effect, at any rate until such time as the decision can be reversed, through an established appellate process.

Second, Article 16 paragraph 4 vests in the DSB alone the decision not to adopt a report by consensus. Where a member through its blocking of the appointment of $\mathrm{AB}$ members, contributes to the usurpation of the DSB's prerogative - that is the collective membership's prerogative not to adopt a panel report, that member is involved in undermining Article 16 paragraph 4 of the DSU. In these circumstances a decision that only the collective membership as a whole can make, is being made effectively by one member, ultimately through its blocking of the appointments in the AB. Moreover, even if a one tier system manages to survive as per the interpretation above, the membership as a whole has been deprived of a benefit they were entitled to under the DSU. In the circumstances, could the US block have an impact on the balance of 'benefits' that members are entitled to and likely to cause a nullification or 
impairment of those benefits? After all the WTO agreements comprise a Single Undertaking wherein there is an interrelationship between the different agreements in the wTо. Is there here a basis for a non-violation complaint or indeed a situation complaint? Could a redress arising from such a complaint, survive even the US departure from the WTO, if there was such a move on the part of the US.

Fourth, given the reform of the DSU was intended to be integral to the totality of any consensus arrived at in the Doha Round, is it permissible that one member can push for one reform in the face of the expressly agreed Doha negotiating modus-operandi? In sum, should responses in the WTO that disproportionately rely on power per se call for legal responses to rein in the abusive use of power?

\section{Inculcating Effective Dispute Settlement Mechanisms in Domestic Systems}

There are several ways in which the wTо has contributed to effective dispute settlement in the domestic trade sphere. Generally first, it has an array of transparency measures ${ }^{12}$ which ensure that domestic administrative and judicial decisions that impact on international trade in goods and services are published; ${ }^{13}$ that relevant institutional decisions and rulings are "uniform, impartial and reasonable" as they relate to international trade; ${ }^{14}$ and that independent "judicial, arbitral or administrative tribunals or procedures" exist for the prompt review of administrative decisions relating to customs issues. ${ }^{15}$ These transparency measures are reinforced by the requirements that member countries need to ensure conformity of their laws and procedures with their obligations under the wTo. ${ }^{16}$ Second, the most-favoured-nation and national treatment standards in the WTO ensure that non-discrimination applies to the judicial institution and its judicial deliberations in so far as it affects the flow of international trade and wTO commitments generally. Thus, the domestic judicial apparatus must result in same treatment as that accorded to nationals and must not result in discrimination as between members of the WTO. Implicit here is also an injunction for judicial independence.

\footnotetext{
12 General Agreement on Trade in Services, art III.

13 General Agreement on Tariffs and Trade, art X.

14 Ibid; Agreement on Trade-Related Aspects of Intellectual Property Rights, art 63.

15 General Agreement on Tariffs and Trade, art X.

16 Agreement Establishing the World Trade Organization, art XVI (4).
} 
Specifically, in different spheres, wTO disciplines focus also on domestic judicial institutions. First, in the sphere of intellectual property rights (IPRs), there is an obligation to ensure effective enforcement mechanisms in the case of infringements of IPRs. ${ }^{17}$ These need to be fair and equitable, not unduly costly and with reasonable time scales accompanied by reasoned decisions in writing. ${ }^{18}$ Furthermore, there has to be provision for judicial review of administrative decisions; ${ }^{19}$ civil judicial procedures for enforcement of intellectual property rights, for example authority to grant injunctions and damages; and provision of criminal process in the case of counterfeits and piracy. Second, in trade remedies, the AD/ASCM and the Safeguards Agreement (SA) necessitate the establishment of Competent Authorities charged with deliberating on the different aspects of these agreements with due process, including establishing judicial review processes of the decisions of the respective Competent Authorities. ${ }^{20}$ In the case of the AD, the wTO panel/AB have oversight of the manner in which domestic Competent Authorities establish facts including whether "their evaluation of those facts was unbiased and objective". ${ }^{21}$

Finally, aspects of enforcement and judicial practice is monitored in the regular trade policy reviews of member countries, although not in depth. For example, in the 2018 trade policy review of China, the following observations were proffered at paragraph 26 in the Secretariat Report: ${ }^{22}$

China's main laws concerning intellectual property rights (IPRs) have remained largely unchanged since its previous Review. Enforcement of IPRs continues to be a major challenge for China. China has continued to strengthen its IPR enforcement, both at the administrative and judicial levels. During the review period, the authorities issued various notices and measures with a view to strengthening China's capacity to protect and enforce IPRs, and 11 additional specialized IPR courts were established by the Supreme People's Court in various cities.

In the same vein, the general and specific provisions outlined earlier have been the subject of deliberation in the WTO dispute settlement, where domestic judicial processes have come under scrutiny. ${ }^{23}$

\footnotetext{
17 Agreement on Trade-Related Aspects of Intellectual Property Rights, art 63.

18 Ibid, art 41.

19 Ibid.

$20 \quad$ Ibid, art 13; Agreement on Subsidies and Countervailing Measures, art 23.

21 Agreement on Implementation of Article VI of GATT 1994, art 17(6) (1).

22 wTo, China Trade Policy Review, 1 October 2018.

23 See for example, wTo, European Communities, 14 December 2006; wTo, Zeroing and Sunset Reviews, 18 August 2009; wTо, Countervailing and Anti-dumping Measures, 27 March 2014 .
} 


\section{Capacity of the wTo Dispute Settlement System in Managing 'Trade Wars'24}

Trade wars in the era of President Trump are of contemporary focus. However, historically trade wars are not new - a classical example being the Opium Wars. Indeed, there has been a fair amount of focus on trade practices in the realms of trade wars. The subject has been considered from different perspectives: international commercial negotiations/diplomacy; economic analysis; and political economy. In particular, there have been case studies of so-called trade wars as between certain countries, and on certain goods or systemic issues, such as, 'bras wars', 'banana wars', 'patent wars' and 'currency wars'. Some of this focus is actually in terms of trade disputes - skirmishes short of trade wars. Importantly, generally the focus is not normative. Moreover, a significant amount of the analysis is at least a decade old.

A fundamental question in a discourse on trade wars is when does a trade dispute partake of a trade war? What is a trade war (contra a trade dispute)? Is a trade war to be understood in terms of the value of the international trade involved? Is it to be understood with reference to the kind of trading nations implicated, along with the consequential spill over effects on the trade of other countries and the world economy? Or is it to be understood with reference to violations of the world trade disciplines under the WTO, and/or under other international law disciplines? From a normative perspective the challenge of trade wars is to determine how best to avert and manage them.

A trade war is not a trade dispute. A trade dispute is specific; it is one that is amenable to being justiciable under an agreed normative framework-very likely under the wTO. However, a trade war may well have its origins in a trade dispute and in principle trade wars can play out both within and outside the WTо. A trade war within the wTO could involve one or a series of disputes involving 'violations' of the WTO agreements but conducted within the framework of the WTo dispute settlement system. A trade war outside the wTo involves a general disregard of the existing normative framework, with a 'gloves off' approach to achieving certain policy goals. As such it can be purely bilateral but where it undermines the international trading order, and the economic interests of a wider circle of countries involving counter-responses, the trade war can partake of a 'world trade war'. Where this trade war is "likely to endanger the maintenance of international peace and security" or becomes a "threat to the peace, breach of the peace, or act of aggression", it could in

24 The first three paragraphs herein reflect the author's written contribution to Hur 2018. 
principle be of interest to the UN Security Council. ${ }^{25}$ Where the trade war impacts on foreign investment, the investment concerns engendered may be the subject of investor State arbitration under the conditions set out in applicable bilateral investment agreements. In the circumstances, the nature of a trade war has significance, albeit in extreme circumstances, with respect to the normative framework within which it needs to be deliberated upon. Recourse to the UN Security Council of course has a political context, in particular where the participants in the trade war are members of the Security Council. Be that as it may, an international consensus that the trade war endangers peace and security or is a threat to the peace, breach of the peace, or act of aggression must of itself carry some weight.

From a Wто perspective, its architects seem to have envisaged a spectrum of possible trade grievances involving 'violations' of the WTо disciplines, including 'non-violations' of the WTO disciplines which nevertheless nullify or impair the benefits a member is entitled to; and grievances arising from the occurrence of a 'situation' known as a 'situation complaint', which affect a member's negotiated benefits. Most disputes between members involve actual violations of provisions of the WTO agreements as such. The full scope of a 'non-violation' and 'situation' complaint is not clear other than the received wisdom that they are applicable in very limited circumstances involving the undermining of tariff undertakings. This breadth of grievances which the wTO dispute settlement mechanism caters for seems to involve all manner of conflicts-from a mere dispute to a situation approximating to a war-but with the important caveat that the grievance should be aired within the framework of the wто dispute settlement system. In such circumstances, there is some scope for a trade grievance to surface and escalate which is outside the WTO managed substantive rights and obligations as such, but which nevertheless can be resolved within the wTo dispute settlement system, assuming it is justiciable.

That said, there are disputes which can fester outside the wTO dispute settlement system, as for example the raising of unbound tariffs as between opposite sides; or where the dispute is of a political/ideological nature, as between market/and State oriented economic doctrines. Of course, all the parties in such circumstances can have recourse to the political organs of the wто to bring about desired changes.

Finally, disputes can play out outside the wто framework, indeed despite it, as in the Trump era. This is because whilst there is a prohibition in the WTO that disputes should be settled within the WTo dispute settlement system, there are no effective sanctions available within the wTO for enforcing its 
internalisation of disputes within the WTO, if the parties together choose to engage with each other outside its framework and/or one or, both of the parties, has the capacity to operate outside the bounds of the WTо. Where however only one party acts in the cover of the WTO, that party may be authorised to retaliate. However, the authority to retaliate including the quantum of retaliation could be informed by the extent to which there has already been the use of unilateral retaliation outside the wTо.

In sum, the capacity of the WTO dispute settlement system to manage socalled trade wars exists. Indeed, it may be asserted that since 1995 the Wто holds a record of managing trade wars-in particular, given that the major trading nations have been active participants in the system. The current strains are in fact symptoms of frustrations that have developed about the system which has been stifled by the lack of reform of the dispute settlement system, including reforms in the substantive law of the Wто. Twenty-four years are indeed a long time for a trading order to have survived without reform. This is both testimony to its success but also its failure for all systems need efficient built-in mechanisms to adapt and rectify their flaws.

Finally, there are two cards that can sometimes trump the operation of the rule of law. The rule of law both underpins an efficient dispute settlement system and is its raison d'être. Both at the national and international levels, national security can act as a procedural and substantive bar to the proper functioning of the dispute settlement system. Thus, in national systems, State immunity and national defence can displace judicial oversight. In international trade, national security can be a tool to displace multilateral oversight. In the same vein, both at the national and international levels, a sense of unfairness, if not properly channelled, can spill over into demonstrations nationally, and unilateral State actions internationally. This is the case even in the most advanced of constitutions and with the most advanced economies.

From the perspective of developing appropriate dispute settlement systems, both nationally and internationally, the parameters of 'national security' need to be more clearly defined, and a measure of judicial oversight clearly demarcated. At the national level, trade policy needs to be sanitised to the extent possible from politics. The emotive backdrop and the amorphous nature of the national security justification, both in international trade law and political economy, provides a perfect Orwellian setting, in which rational discourse and judicial scrutiny can be inhibited; and a universe of grievances placed on the foreign relations agenda, not to mention the accompanying performance for the domestic audience.

At a time when national security is no longer articulated in a defensive context alone, but understood in terms of world pre-eminence, the context 
of national security in the international trading order evokes the adage of the camel's nose in the trade tent! In other words, once national security considerations are admitted, they soon takeover the trade dimension. Moreover, not only has 'national security' in international State practice subsumed within it the circumstance of a State's 'economic security'; globalisation and the consequent interdependence of economic and non-economic policy instruments, including the multiple value chains involved in the manufacture of a product, has brought to the fore the need to de-couple as much as it is possible national security issues, from purely economic considerations, in trade policy making. Thus, in the International Monetary Fund, Central Bank involvement through a good governance approach endeavours to ensure the independence of Central Banks from interference from other organs of the State. In trade policy making, the executive and legislative branches are closely involved in trade policy making. There is no effort for a constitutional set up that endeavours to minimise (granted it is not possible to exclude completely) the involvement of political considerations in national trade policy making, through for example, proper constitutional checks and balances.

In the same vein, 'unfair' can be a populist emotive chant-an indeterminate empowering concept, justifying extraordinary measures. The instrument of 'unfair trade' as a sword in international economic relations, is set in the residual economic sovereignty of a State, that the State believes it has always at its disposal, no matter how much it has been sheathed or blunted through membership of the WTO. Nevertheless, just as in domestic systems wherein proper constitutional processes need to be established for all stakeholders to be involved in the national trade policy reform process, at the multilateral level some of the systemic issues in the WTO legislative processes need to be further fine-tuned, as for instance consensus decision-making.

One question that is central to the management of trade wars within the framework of the rule of international law, whether in the context of the WTO and/or outside it, is the manner in which the system of adjudication should respond to participants who are cloaked with a super power status. To some there is no such question that even arises since the rule of international law is underwritten by the equality of States and a system of adjudication should be blind to any such status. The system of legislation and the nature of the rule may however be so informed in its design and consequent outcome. On the other hand, there are arguments that seem to challenge this equality narrative even at the level of adjudication. One such school is set in the approach to law not as a set of rules but as a process of decision-making wherein law/policy and power are set on the same plain. History and the international legal order 
may reflect this narrative but equally the historical march of the development of the international economic order has a trajectory affirming the rule of international law. For the present, the pendulum may seem to swing one way but the long-term underlying thrust will be informed by the rule of law. This is indispensable in the sphere of international economic relations wherein ultimately the market informs the exchanges that take place as between the residents of different States. The rule of law is a condition for the smooth operation of markets and the confidence of the individual actors engaged in economic transactions across national borders.

In sum, the challenge of managing trade wars in such circumstances rest in a holistic approach over a continuum of time. Both legitimate concerns about the dispute settlement system and substantive law of the wTO needs to be addressed - as indeed should the rigour of the rule of law be applied to an abusive use of the consensus decision making process.

The functioning of the dispute settlement system in the wTо has a bearing on good governance aspects of foreign trade in the domestic sphere. Equally, an effective dispute settlement system in the wTO ultimately empowers domestic stakeholders with the rule of law in international trade not to mention member States of the WTO. International financial and development institutions along with the International Law Commission have a role to play in ensuring the effectiveness of the WTO dispute settlement system albeit indirectly. First, there is the need for a comprehensive worldwide survey of the manner in which national security is set in national constitutions - in terms of clarity of its definition, the manner of its invocation and the extent to which it is subject to constitutional checks and balances. The world order is based alas, on the holy grail of the State system and its sovereignty. This does not however mean that there cannot be a rational discourse with respect to it. A first preliminary for this is this global survey. This can then feed into some form of a framework informed by good governance- - a perspective a number of multilateral financial institutions have the mandate to promote. Second, the national security exception is found in many bilateral and multilateral instruments. Its scope however is often indeterminate. Thus, prospective candidates for judicial appointments in international courts including the $\mathrm{AB}$ of the WTO (the author here speaks from personal experience) are often asked how they would interpret the national security exception. There has to be clarity on this question. 


\section{Reference List}

Agreement Establishing the World Trade Organization (1994).

Agreement on Implementation of Article vi of the General Agreement on Tariffs and Trade (15 April 1994) LT/UR/A-1A/3 <http://docsonline.wto.org> accessed on 22 February 2019.

Agreement on Subsidies and Countervailing Measures (15 April 1994) LT/UR/A-1A/9 $<\mathrm{http}$ ://docsonline.wto.org > accessed on 22 February 2019.

Agreement on Trade-Related Aspects of Intellectual Property Rights (15 April 1994) LT/UR/A-1C/IP/1 <http://docsonline.wto.org > accessed on 22 February 2019.

Bhatia U, 'Address on 11th Annual Update on WTO Dispute Settlement Address' (Graduate Institute, 3 May 2018) <http:/graduateinstitute.ch/files/live/sites/iheid/ files/sites/ctei/shared/News\%26Events/CTEI\%2oNews\%202018/Ujal\%2oSingh\% 2oBhatia\%2o(AB\%2oChair)\%2oGraduate\%2oInstitute\%2oSpeech\%20-3\% 20May\%202018.pdf> accessed on 22 February 2019.

Fabry E and Tate E, 'Saving the WTO to Appellate Body or Returning to the Wild West of Trade?' (Notre Europe Institut Jacques Delors, 7 June 2018) < http://institutdelors .eu/wp-content/uploads/2018/05/SavingtheWTOAppellateBody-FabryTate -June2018.pdf $>$ accessed on 22 February 2019.

General Agreement on Tariffs and Trade (15 April 1994) LT/UR/A-1A/1/GATT/1<http:// docsonline.wto.org > accessed on 22 February 2019.

General Agreement on Trade in Services (15 April 1994) LT/UR/A-1B/S/ <http://docs online.wto.org> accessed on 22 February 2019.

Hur N, 'Historical and Strategic Concern over the US-China Trade War: Will they be within the WTO?' (2018) 11 Journal of East Asia and International Law 393.

International Centre for Trade and Sustainable Development, 'WTO Members Intensify Debate Over Resolving Appellate Body Impasse' (2018) 22 Bridges <https:// www.ictsd.org/bridges-news/bridges/news/wto-members-intensify-debate-overresolving-appellate-body-impasse $>$ accessed on 22 February 2019.

Office of USTR, '2018 Trade Policy Agenda and 2017 Annual Report of the President of the United States on the Trade Agreements Program' (Office of USTR, March 2018) <https:/ustr.gov/sites/default/files/files/Press/Reports/2018/AR/2018\%20 Annual\%2oReport\%2oFINAL.PDF $>$ accessed on 22 February 2019.

Qureshi A and Ziegler A, International Economic Law (Sweet \& Maxwell 2011).

Salles L E, 'Bilateral Agreements as an Option to Living through the WTO AB Crisis' (IELPO Blog, 23 November 2017) < worldtradelaw.typepad.com/ielpblog/2017/11/ guest-post-on-bilateral-agreementsas-an-option-to-living-through-the-wto-ab -crisis.html> accessed on 22 February 2019.

U.S. Mission to the International Organization in Geneva, 'Statements by the United States at the Meeting of the WTO Dispute Settlement Body' (the Meeting of 
the WTO Dispute Settlement Body, Geneva, 27 August 2018) <https://geneva. usmission.gov/wp-content/uploads/sites/29o/Aug27.DSB_.Stmt_.as-delivered.fin _.public.pdf $>$ accessed on 22 February 2019.

Understanding on Rules and Procedures Governing the Settlement of Disputes (15 April 1994) LT/UR/A-2/DS/U/1 <http://docsonline.wto.org> accessed on 22 February 2019.

United Nations Charter (1945) (signed 26 June 1945, entered into force 24 October 1945) 1 UNTS XVI.

WTO, European Communities-Selected Customs Matters (14 December 2006) $\mathrm{WT} / \mathrm{DS}_{315} / 15$.

WTO, USA: Measures Relating to Zeroing and Sunset Reviews Recourse to Article 21.5 of the DSU (18 August 2009) WT/DS $322 / \mathrm{AB} / \mathrm{RW}$.

WTO, USA: Definitive Anti-Dumping and Countervailing Duties on Certain Products from China (11 March 2011) WT/DS379/AB/R.

WTO, USA: Countervailing and Anti-dumping Measures on Certain Products from China (27 March 2014) WT/DS449/R.

WTO, China Trade Policy Review Secretariat Report (1 October 2018) WT/TPR/S/380. 